\title{
Visual Naked Eye Colorimetric Determination of Phorate Pesticide Using Nanotechnology
}

\author{
Rajat Singh*, Naveen Kumar \\ Amity University Rajasthan-Jaipur, 303002 India
}

(Received 10 January 2021; revised manuscript received 23 March 2021; published online 09 April 2021)

\begin{abstract}
Here, in this study citrate-gold, NPs was prepared and used for visual recognition of phorate pesticide. The synthesized gold NPs were characterized using UV-visible spectroscopy, dynamic light scattering and transmission electron microscopic techniques. The developed method is simple and easy to operate. The detection requires only the addition of phorate into colloidal gold NPs solution. Phorate induced the aggregation of gold NPs resulting in the color transformation from wine-red to blue and alteration in SPR spectra from $520 \mathrm{~nm}$ to $658 \mathrm{~nm}$ was observed. The color change was easily assessed by bare eye and absorption spectra were measured using UV-visible spectroscopy. Moreover, the developed method will be a promising tool for on-site determination of phorate in real environmental samples.
\end{abstract}

Keywords: Colorimetric, Au NPs, Phorate, Pesticides, Onsite.

DOI: 10.21272/jnep.13(2).02015

PACS numbers: 61.46.Df, 68.37.Ef

\section{INTRODUCTION}

Pesticides are organic or inorganic chemical compounds intended for preventing, destroying and resisting or vindicating insect and pest [1]. The pest and disease every year decimate $50 \%$ of the world's agricultural produce during harvesting, storage and transportation [2]. Hence, to protect the agricultural produce from the harm of insect-pest farmers are using pesticides. More than 1000 different types of pesticides including organochlorine, organophosphate, carbamates and pyrethroids are used worldwide for controlling of insect-pests [3]. Among all pesticides, organophosphate class of pesticides are most commonly used in agriculture because of their acute toxicity and less persistence nature. But due to the excessive and widespread use of these chemical pesticides in agricultural, the metabolites of these pesticides are appearing in our diet which causes serious health problems.

Organophosphate pesticides exhibit acute toxic effects on the human nervous system and the long-term exposure to these pesticides cause the nerve cell death by the accumulation of acetylcholine enzyme [4]. Phorate is generally used for preventing and controlling insects, mites and certain nematodes in agriculture. It is easily oxidized into two compounds i.e. sulphoxide and sulphone when coming in contact with soil and their phosphorothioate analogues are then hydrolyzed further to simple substances and bioaccumulate in the soil, food and water bodies [5].

These facts highlight that it becomes essential to monitor the concentration of phorate pesticides in environmental samples. For that, a simple, rapid, on-site detection method for monitoring the concentration of phorate in water samples is required. In general, there are several conventional techniques which are used for the monitoring of pesticides namely gas chromatography (GC), mass spectroscopy (MS), HPLC and FTIR [6-7]. These techniques are good and provide the advantages in term of sensitivity, accuracy but these techniques have some disadvantages such as cost, long analysis time, complex instrumentation.

In recent years, nanotechnology has been widely explored for the development of simple analytical tools for colorimetric detection of heavy metal ions, proteins, and other biological molecules [8]. Nanoparticles based colorimetric detection techniques are very simple, costeffective and provides good sensitivity [9-10]. Therefore, here in this study, we developed a gold NPs-based colorimetric probe for visual determination of phorate pesticide. Phorate promoted the aggregation of gold NPs and induced color transition from red to blue which was observed using the bare eye. The absorption spectra were recorded using UV-visible spectroscopy while TEM and DLS techniques are used for validation of the assay mechanism

\section{MATERIAL AND METHODS}

Gold chloride, tri-sodium citrate was purchased from Sigma-Aldrich USA. Phorate was purchased from the Jaipur, India. All chemicals are of analytical grade and used without further purification. All glassware treated with $\mathrm{HNO}_{3}$ and $\mathrm{HCl}$ (1:3) and rinse with distilled water $\left(\mathrm{dH}_{2} \mathrm{O}\right)$ and dry in the oven. High-grade research water was used in entire practical work.

\subsection{Instrumentation}

Absorption spectra were recorded using UV-visible spectrophotometer (Genesis-180). Transmission electron microscopy (TEM) images were recorded using (TECNAI G ${ }^{2}$ 3000). Particles size of prepared NPs was obtained using dynamic light scattering (Malvern, zetasizer, UK).

\subsection{Preparation of Gold Nanoparticles}

Gold NPs were synthesized according to the previous procedure followed by [10] with certain modifications. Gold chloride $(3 \mathrm{mM}), 10 \mathrm{ml}$ solution was diluted to a $100 \mathrm{ml}$ with double distilled water in a $250 \mathrm{ml} \mathrm{re}$ -

\footnotetext{
*rsft95@gmail.com

The results were presented at the International Conference on Multifunctional Nanomaterials (ICMN2020)
} 
action flask. The reaction flask was continuous heat and stirred till the boiling using a magnetic stirrer. Then, $10 \mathrm{ml}$ trisodium citrate $(23 \mathrm{mM})$ was added dropwise to the reaction flask and continuously stirred for next $15 \mathrm{~min}$. The change in color of the light-yellow solution of gold chloride to red confirms the formation of gold NPs.

\subsection{Gold Nanoparticles Used as Colorimetric Probe}

For colorimetric detection of phorate, $0.4 \mathrm{~mL}$ of gold NPs were added separately to $2 \mathrm{ml}$ sample vials and then $0.2 \mathrm{ml}$ of different concentration of phorate (50$250 \mu \mathrm{M})$ was added, the resulting solution was well shaken and after 5 min color of the solution changed from red to blue with an increasing concentration of phorate. The photographs and UV-visible spectroscopy spectra of the above samples were recorded and further characterized using TEM and DLS, respectively.

\section{RESULTS AND DISCUSSION}

Gold NPs were prepared using chemical reduction of gold chloride solution using citrate as reducing as well as the stabilizing agent. The change in color of gold chloride solution from light yellow to wine-red with the addition of citrate solution under continuous stirring and heating confirms the synthesis of gold NPs. A large number of negative ions present in citrate help in maintaining the stability of the colloidal suspension of gold NPs for a longer time. The wine-red color of synthesized gold NPs was easily visualized using the naked eye and the absorption SPR spectra of gold NPs was measured using UV-visible spectroscopy. The gold NPs have important optical characteristics and showed a distinct SPR band in visible range 400 to $800 \mathrm{~nm}$ in the electromagnetic spectrum. Fig. 1 shows the UV-visible spectra and photographs of prepared gold NPs.

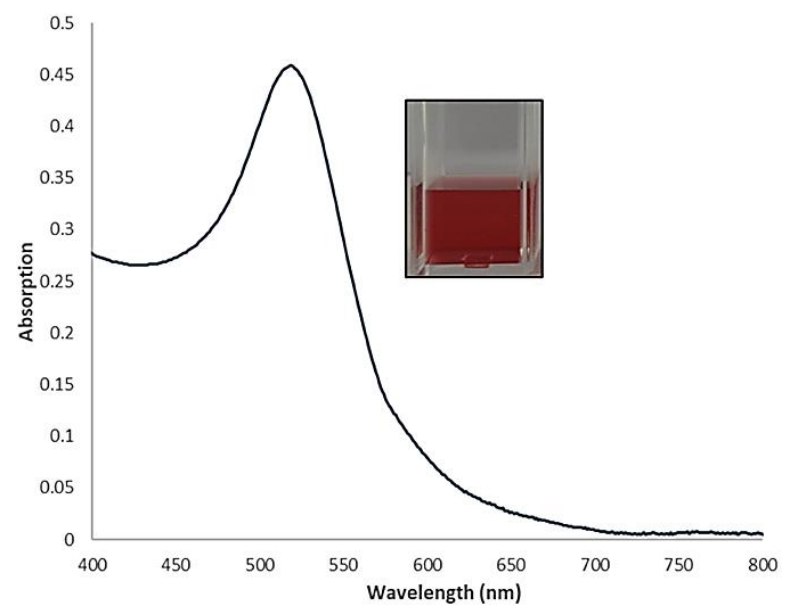

Fig. 1 - UV-visible absorption spectra and the photograph of prepared gold NPs

\section{TEM and DLS Analysis}

The morphology and particle size of prepared gold NPs was evaluated using the transmission electron microscopy and dynamic light scattering techniques. The results of TEM analysis stated that the prepared gold NP was spherical and well dispersed in nature (Fig. 3a). DLS is an important tool which highly used in analytical nanotechnology to determine the particle size of the metal NPs. Fig. 4a shows the core size of the prepared gold NPs was around $27 \mathrm{~nm}$.

\section{Colorimetric Sensing of Phorate Pesticide}

For colorimetric sensing of the phorate pesticide using cit-gold NPs different concentration of phorate (50$250 \mu \mathrm{M})$ was added to the prepared cit-gold NPs solution. After a few minutes, the color change from red to blue was observed and the LSPR spectra $(520 \mathrm{~nm})$ of cit-gold NPs was decreased and new absorption spectra at $658 \mathrm{~nm}$ appeared. Fig. 2 shows that the absorption spectra and photographs with the addition of phorate in the presence of gold NPs. Furthermore, the mechanism of the assay was verified using the TEM and DLS methods. TEM is an important technique used for studying the surface morphology of metal NPs. TEM (Fig. 3) demonstrated that the prepared NPs were welldispersed in aqueous medium and after the addition of phorate solution to the colloidal cit-AuNPs solution the morphology of cit-gold NPs was significantly changed indicating the strong interaction of phorate with citgold NPs. Similarly, DLS analysis suggested that the average particle size of gold NPs was around $27 \mathrm{nM}$ and after the addition of the phorate to cit-gold NPs the particle size of cit-gold NPs was significantly increased to $182 \mathrm{~nm}$ indicating that phorate induced the aggregation of gold NPs. These findings suggest that cit-gold NPs will be an important tool for visual determination of phorate in the real matrix.

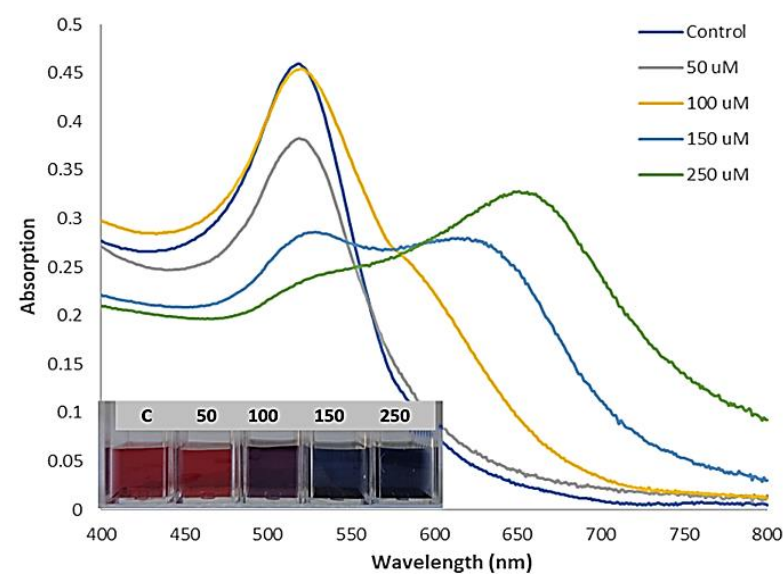

Fig. 2 - UV-visible spectra and photographs of cit-gold NPs with different concentration of phorate

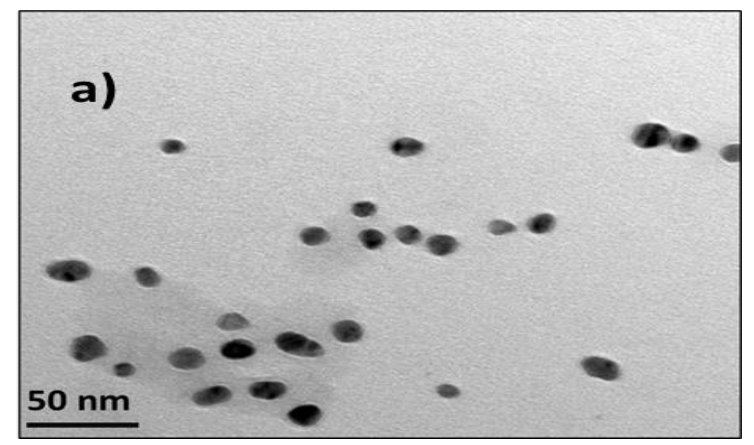




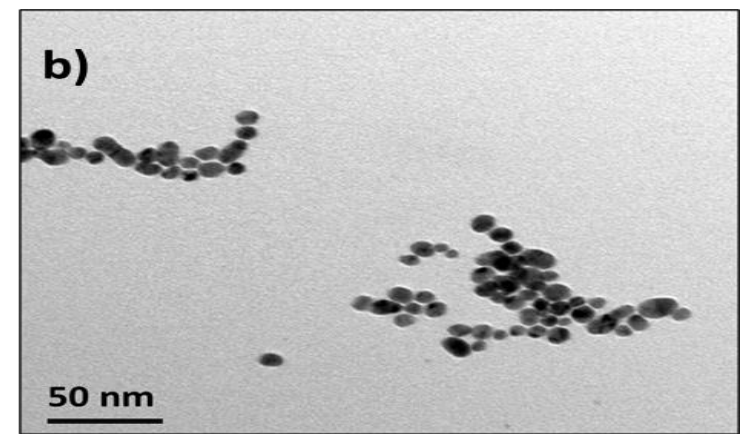

Fig. 3-TEM monographs of cit-gold NPs: a) without and b) with the addition of phorate
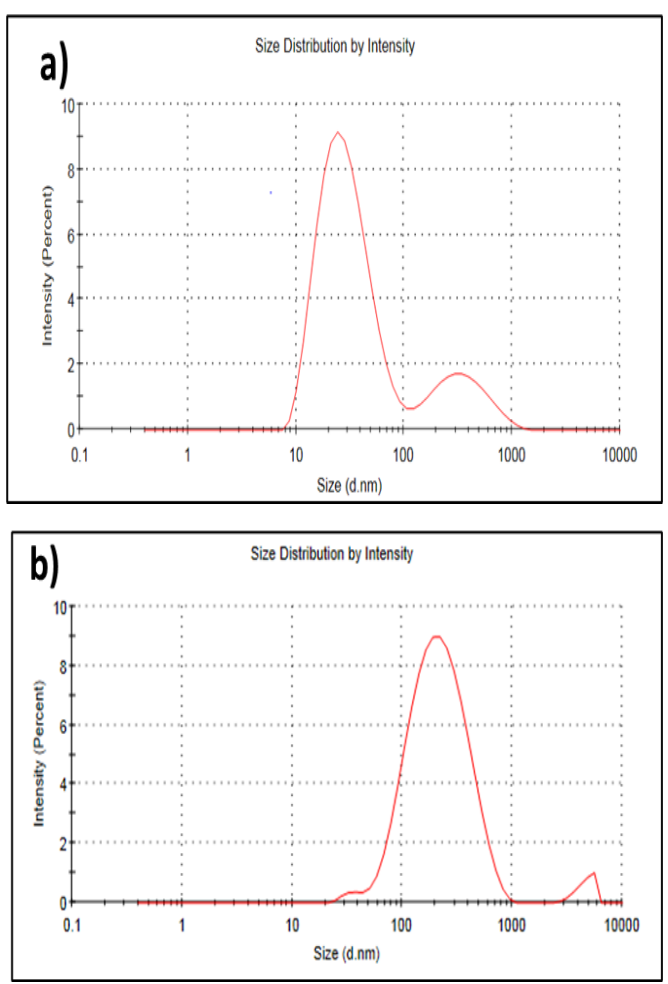

Fig. 4 - The particle size distribution of cit-gold NPs a) without and b) with the addition of phorate

\section{REFERENCES}

1. P. Chawla, R. Kaushik, V.S. Swaraj, N. Kumar, Environ. Nanotechnol. Manag. 10, 292 (2018).

2. R. Singh, P. Thakur, A. Thakur, H. Kumar, P. Chawla, V.J. Rohit, R. Kaushik, N. Kumar, Int. J. Environ. Anal. Chem. 22, 7 (2020).

3. R. Singh, N. Kumar, R. Mehra, H. Kumar, V.P. Singh, Trends Environ. Anal. Chem. 27, 00086 (2020).

4. D.N. Kumar, A. Rajeshwari, S.A. Alex, M. Sahu, A.M. Raichur, RSC Adv. 5, 61998 (2015).

5. N. Kumar, A.K. Pathera, P. Saini, M. Kumar, Ann. Agri-

\section{Interference Study}

To determine the sensitivity, we analyzed chlorpyrifos, malathion, and monocrotophos using a developed assay with a similar procedure used for detection of phorate. The findings showed that no spectra or visual color change were noticed after addition of other pesticides into a colloidal solution of cit-gold NPs indicating that the developed probe is only sensible for determination of phorate (Fig. 5).

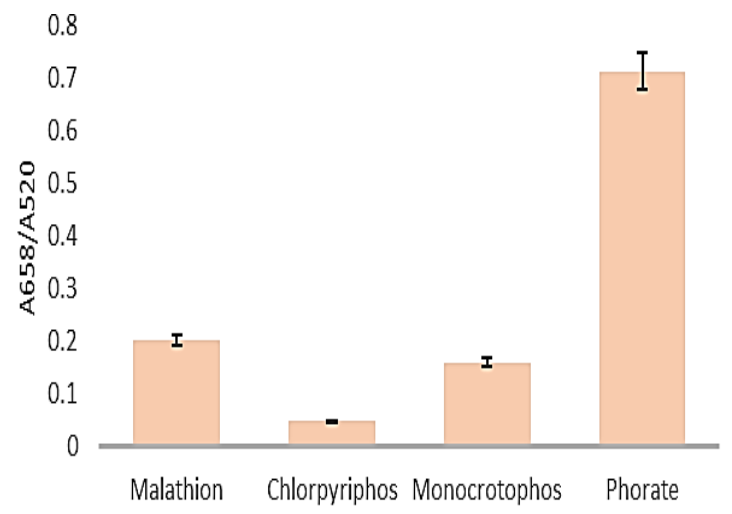

Fig. 5 - Interference study with other pesticides

\section{CONCLUSIONS}

Metal NPs have important optical characteristics such as high extinction coefficient due to these excellent properties they are successfully used for the development of colorimetric sensors for determination of various analytes. Here, in this study, we synthesized the gold NPs using citrate as reducing and stabilizing agent and used for colorimetric determination of phorate. Phorate induced the aggregation of gold NPs and induced the color change from red to blue which was further verified using UV-visible spectroscopy, DLS and transmission electron microscopy. Hence, it showed that prepared gold NPs has a high potential for the determination of phorate in real water samples.

Bio. Res. 17, 125 (2012)

6. A. Wilkowska, M. Biziuk, Food Chem. Apr. 125, 803 (2015).

7. E.M. An, H.S. Shin, Food Sci. Biotechnol. 20, 1299 (2011).

8. A. Amirjani, M. Bagheri, S. Hesaraki, Nanotechnology 27, 375503 (2016).

9. N. Kumar, H. Kumar, B. Mann, R. Seth, Spectrochim. Acta A: Mol. Biomol. Spectrosc. 5, 89 (2016).

10. N. Kumar, R. Seth, H. Kumar, Anal. Biochem. 456, 43 (2014). 


\title{
Колориметричне визначення форатного пестициду з використанням нанотехнологій
}

\author{
Rajat Singh, Naveen Kumar
}

Amity University Rajasthan-Jaipur, 303002 India

\begin{abstract}
У дослідженні наночастинки цитрату золота були підготовлені і використані для візуального розпізнавання форатного пестициду. Синтезовані наночастинки золота (Au NPs) характеризувались за допомогою методів UV-Vis спектроскопії, динамічного розсіювання світла та просвічуючої електронної мікроскопії. Розроблений метод простий і зручний в експлуатації. Для діагностики потрібно лише додавання форату в розчин колоїдних Au NPs. Форат викликав агрегацію Au NPs, що призводило до зміни кольору від винно-червоного до синього і спостерігалася зміна в спектрах SPR від 520 до 658 нм. Зміну кольору легко оцінювали неозброєним оком, а спектри поглинання вимірювали за допомогою UV-Vis спектроскопії. Більше того, розроблений метод е перспективним інструментом для локального визначення форату в реальних зразках навколишнього середовища
\end{abstract}

Ключові слова: Колориметричний, Au NPs, Форат, Пестициди, Локальний. 